\title{
MANFAAT IKAN TERI SEGAR (Stolephorus sp) TERHADAP PERTUMBUHAN TULANG DAN GIGI
}

\author{
Endah Aryati E*, Agustin Wulan Suci Dharmayanti ${ }^{* *}$
}

\begin{abstract}
Keywords: anchovies, calcium, protein, teeth, bone

Background: Nutrition and diet intake are such related with growth and development of body organs, including growth and development of bone and teeth. High quality and concentration of protein and cancium in food have linier relationship with growth and development of bone and teeth. Anchovies are high quality protein and calcium source. Anchovies are cheap calcium and protein source that can be available in Indonesia. This review was aimed to review the benefits of anchovies to development of bone and teeth. Discussion : DisAnchovies are high quality food because all of the body can be consumed. Bone of anchovies contains protein and calcium. Per $100 \mathrm{gram}$ of anchovies contain $77 \mathrm{kcal}$ of energy; 16 gr protein; $1.0 \mathrm{gr}$ fat; $500 \mathrm{mg}$ calcium; 500 mg phosfor; $1.0 \mathrm{mg}$ ferrum; $47 \mathrm{Vit} \mathrm{A}$; and $0.1 \mathrm{mg}$ Vit B. Protein and calcium were needed by body fore repairing process and structed the tissue. Protein was as bone matrix. Calcium of anchovies was good for bone, teeth and had calming effect. Moreover, vitamin A of anchovies was also important for bone and teeth development. Conclusion: anchovies could be used as essential nutrition to optimal of bone and teeth development.
\end{abstract}

\section{PENDAHULUAN}

Nutrisi penting untuk seluruh proses metabolisme di dalam tubuh. Nutrisi dan diet intake sangat berhubungan dengan pertumbuhan dan perkembangan seluruh organ tubuh, termasuk pertumbuhan dan perkembangan tulang dan gigi. Pemilihan jenis makanan sepanjang kehidupan akan menentukan status pertumbuhan dan perkembangan gigi dan tulang, terutama makanan dengan tinggi protein dan kalsium. Makanan dengan kualitas dan konsentrasi protein dan kalsium yang tinggi mempunyai hubungan linier dengan pertumbuhan dan perkembangan tulang dan gigi. Hal ini disebabkan protein merupakan makanan yang mengandung banyak asam amino sebagai unsur pembangun struktur jaringan tubuh, sedangkan kalsium merupakan mineral penting yang berperan dalam seluruh proses metabolisme tulang dan gigi. ${ }^{1}$

Gangguan pertumbuhan dan perkembangan tulang dan gigi serta kelainan tulang dan gigi penduduk Indonesia cukup tinggi, kejadian ini dihubungkan dengan daya konsumsi makanan tinggi protein dan kalsium penduduk Indonesia masih cukup rendah. Kondisi ini sangat disayangkan, karena Indonesia merupakan negara kaya dengan sumber daya alam, terutama sumber daya kelautan, terutama ikan. Ikan merupakan sumber protein dan kalsium dengan kualitas tinggi. Kandungan gizi ikan ini sangat bagus untuk tulang dan gigi. Dari berbagai jenis ikan, ikan teri baik segar maupun kering mempunyai

*Staf Pengajar Jurusan Keperawatan Gigi Politeknik Kesehatan Kemenkes Semarang, **Departemen Biomedik Fakultas Kedokteran Gigi Universitas Jember

Korespondensi: endahsmg@yahoo.com 
kandungan protein dan kalsium tertinggi. ${ }^{2}$ Ikan teri merupakan sumber kalsium dan protein yang murah serta banyak tersedia di seluruh pelosok Indonesia. Akan tetapi, informasi tentang manfaat ikan teri bagi pertumbuhan tulang dan gigi masih kurang. Kajian pustaka ini bertujuan untuk menjelaskan manfaat konsumsi ikan teri terhadap pertumbuhan tulang dan gigi.

\section{TINJAUAN PUSTAKA \\ Morfologi Ikan Teri (Stolephorus sp.)}

Ikan teri merupakan ikan yang berada di daerah perairan pesisir dan eustaria dengan tingkat keasinan 10-15\%. Ikan teri hidup berkelompok yang terdiri dari ratusan sampai ribuan ekor. Ikan teri berukuran kecil dan besarnya ukuran bervariasi yaitu antara 6-9 cm. Gambaran morfologi ikan teri yaitu sirip caudal bercagak dan tidak bergabung dengan sirip anal, duri abdominal hanya terdapat sirip pektoral dan ventral, tidak berwarna atau agak kemerah-merahan. Bentuk tubuhnya bulat memanjang (fusiform) atau agak termampat kesamping (compressed), pada sisi samping tubuhnya terdapat garis putih keperakan memanjang dari kepala sampai ekor. Sisiknya kecil dan tipis sangat mudah lepas, tulang rahang atas memanjang mencapai celah insang. Giginya terdapat pada rahang, langitlangit palatin, pterigod, dan lidah. ${ }^{3}$

Taksonomi Ikan Teri (Stolephorus sp.) Klasifikasi ikan teri adalah sebagai berikut: ${ }^{4}$

$\begin{array}{ll}\text { Filum } & \text { : Chordata } \\ \text { Sub-filum } & \text { : Vertebrata } \\ \text { Kelas } & \text { : Pisces } \\ \text { Sub-kelas } & \text { : Teleostei } \\ \text { Ordo } & \text { : Malacopterygii } \\ \text { Famili } & \text { : Clopeidae } \\ \text { Sub-famili } & \text { : Engraulidae } \\ \text { Genus } & \text { : Stolephorus } \\ \text { Spesies } & \text { : Stolephorus sp. }\end{array}$

Kandungan Gizi Ikan Teri (Stolephorus sp.)

Ikan teri merupakan ikan teri merupakan makanan kualitas tinggi karena seluruh bagian tubuhnya dapat dikonsumsi. Tulang ikan teri banyak mengandung protein dan kalsium. Tiap 100 gram teri segar mengandung energi 77 kkal; protein 16 gr; lemak 1.0 gr; kalsium 500 mg; phosfor 500 mg; besi 1.0 mg; Vit A 47; dan Vit B $0.1 \mathrm{mg}^{5}$

Kandungan gizi ikan teri baik segar maupun kering lebih tinggi dibanding dengan ikan yang lain (tabel 1 ). ${ }^{2}$

\section{Gigi dan Tulang}

Tulang dan gigi merupakan jaringan keras pada mamalia. Tulang dan gigi adalah jaringan keras yag termineralisasi dan mengandung protein. Secara struktural, tulang terdiri dari tulang kompak, spongiosa dan sumsum tulang. Sumsum tulang terdapat di dalam tulang spongiosa yang menyediakan darah untuk aktivitas metabolisme dalam tulang. Gigi secara struktural terdiri dari enamel, dentin, sementum dan pulpa gigi. Pulpa gigi berfungsi menyediakan nutrisi untuk gigi. Komposisi utama tulang dan jaringan keras gigi adalah matriks ektraseluler termineralisasi yang mengandung bahan organic dan anorganik, seperti mineral kalsium, fosfor dan protein. Deposisi mineral pada matriks tulang menyebabkan menjadi kuat sehingga dapat menahan beban berat tubuh, membentuk rangka tubuh dan menjadi perlekatan bagi otot serta melindungi organ-organ penting dalam tubuh. Kuat dan lemahnya tulang ini dipengaruhi oleh matrik penyusun tulang yang mengandung banyak mineral didalamnya.Matrik tulang ini terdiri dari osteoblas, osteosit dan osteoklas. ${ }^{6}$

Tulang, dentin dan sementum secara umum mempunyai kemiripan, akan tetapi dalam beberapa aspek berbeda. Selama kehidupan, jaringan tulang selalu melakukan proses remodeling yang berjalan secara kontinue. Dentin dan 
Tabel 1. Kandungan Gizi Ikan2

\begin{tabular}{|l|c|c|c|c|c|c|}
\hline \multicolumn{1}{|c|}{ Jenis } & $\begin{array}{c}\text { Energy } \\
(\mathbf{k a l})\end{array}$ & $\begin{array}{c}\text { Prorein } \\
(\mathbf{g})\end{array}$ & $\begin{array}{c}\text { Lemak } \\
(\mathbf{g})\end{array}$ & $\begin{array}{c}\text { Kalsium } \\
(\mathbf{m g})\end{array}$ & $\begin{array}{c}\text { Fosfor } \\
(\mathbf{m g})\end{array}$ & $\begin{array}{c}\text { Zat Besi } \\
(\mathbf{m g})\end{array}$ \\
\hline Bandeng & 129 & 20 & 4.8 & 20 & 150 & 2 \\
\hline Gabus & 74 & 25.2 & 1.7 & 62 & 176 & 47 \\
\hline Ikan asin & 193 & 42 & 1.5 & 200 & 300 & 2.5 \\
\hline Ikan mas & 86 & 16 & 2 & 20 & 150 & 2 \\
\hline Ikan kembung & 103 & 22 & 1 & 20 & 200 & 1 \\
\hline Lele goreng & 252 & 19.9 & 19.1 & 23.8 & 232 & 1.2 \\
\hline Selar & 142 & 27 & 3 & 60 & 200 & 3 \\
\hline Rebon segar & 81 & 16.2 & 1.2 & 757 & 292 & 2.2 \\
\hline Rebon kering & 299 & 29.4 & 3.6 & 2306 & 255 & 21.4 \\
\hline Sarden & 338 & 21.1 & 27 & 354 & 434 & 3.5 \\
\hline Teri bubuk & 227 & 60 & 2.3 & 1209 & 1225 & 3 \\
\hline Teri kering & 170 & 33.4 & 3 & 1200 & 1500 & 3.6 \\
\hline Teri segar & 144 & 32.5 & 0.6 & 1000 & 1000 & 3 \\
\hline Mujair & 89 & 19.7 & 1 & 96 & 29 & 1.5 \\
\hline Udang kering & 295 & 62.4 & 2.3 & 1209 & 1225 & 6.3 \\
\hline
\end{tabular}

sementum tidak melakukan remodeling, akan tetapi mereka mempunyai kemampuan untuk menjaga stabilitas selselnya dengan cara membentuk jaringan reparasi. $^{7}$

Gigi geligi tertanam dalam tulang rahang yang merupakan tulang kompak. Pertumbuhan dan perkembangan tulang rahang berhubungan erat dengan maturasi tulang secara umum dan ada korelasi yang positif dengan maturasi gigi geligi. Basaran dkk mengemukakan bahwa ada hubungan yang signifikan antara maturasi skeletal dengan gigi geligi. Maturasi gigi geligi dapat ditentukan dari sejak erupsi, juga dapat ditentukan dari kalsifikasi gigi tersebut. Chen menyatakan bahwa kalsifikasi gigi merupakan gambaran yang jelas dalam menentukan maturasi gigi geligi dan gambaran kalsifikasi dapat diobservasi melalui radiografi. ${ }^{8}$

\section{DISKUSI}

Tingkat status gizi penduduk Indonesia masih cukup rendah. Hal ini dipengaruhi oleh beberapa faktor, salah satunya daya beli masyarakat akan makanan bergizi yang dan tingkat pengetahuan masyarakat tentang makan bergizi yang murah masih rendah. Indonesia merupakan negara maritim yang mampu menghasilkan sumber daya alam kelautan yang bernilai tinggi. Sumber daya alam kelautan ini seperti ikan mempunyai nilai gizi yang sangat tinggi, terutama ikan teri. Ikan teri merupakan ikan berukuran kecil yang dapat dikonsumsi seluruh bagian tubuhnya, sehingga ikan teri dijadikan sumber kalsium dan protein tinggi. Adapun daya jual ikan teri relative murah, sehingga masyarakat dapat mengkonsumsi ikan teri ini dengan harga beli yang relatif murah.

Ikan teri banyak mengandung protein dan kalsium. Kedua zat gizi ini sangat diperlukan oleh tubuh untuk proses perbaikan dan membangun jaringan, terutama jaringan tulang dan gigi. Kualitas dan konsentrasi protein yang tinggi dalam makanan merupakan faktor penting dalam proses fisiologis pertumbuhan dan perkembangan jaringan keras tubuh, terutama tulang rahang dan dan gigi. Kebutuhan nutrisi bergizi tinggi masyarakat, terutama ibu hamil dan balita mempunyai korelasi yang kuat dengan pertumbuhan dan perkembangan tulang 
dan gigi geligi anak. Pengaruh khususnya pada proses pembentukan enamel dan dentin gigi decidui dan permanen selama pertumbuhan fetus. Selain itu, nutrisi ini juga berfungsi menjaga homeostasis pada ibu selama proses kehamilan. Apabila keseimbangan kalsium dan protein kurang untuk asupan fetus, maka sumber kalsium dan protein pada tulang dan gigi ibu hamil akan dirombak dan didistribusikan pada fetus. Hal ini akan berdampak pada kepadatan tulang dan gigi, yang berakibat pada pengeroposan tulang dan gigi. ${ }^{9}$

Beberapa penelitian menunjukkan bahawa kekurangan protein akan menyebabkan gangguan pertumbuhan dan perkembangan kolagen dan mineral jaringan keras tubuh, dalam hal ini tulang dan gigi. Kekurangan protein akan menyebabkan kekuatan dan elastisitas tulang dan gigi berkurang, terutama tulang rahang. ${ }^{1}$

Walaupun tulang rahang berbeda dengan tulang tubuh lainnya, akan tetapi tulang rahang mempunyai fungsi yang sangat komplek terutama pada saat proses pengunyahan. Carlos dkk menunjukkan bahwa kekurangan protein berakibat pada pengurangan jumlah sub unit fungsional skeletal rahang, yang berdampak pada perubahan proporsi dan deformasi tulang mandibula, berupa penurunan densitas tulang rahang. Penurunan densitas tulang rahang menyebabkan tulang penyokong gigi krang adekuat, sehingga gigi tidak dapat bertahan lama dalam soket gigi dan terjadi gangguan pengunyahan. ${ }^{1}$

Protein berfungsi sebagai pembentuk matriks organik tulang. Matrik organic tulang ini merupakan tempat deposisi ion mineral pada proses kalsifikasi tulang, yaitu ion kalsium dan fosfor. Fungsi protein yang berkaitan dengan kalsium yaitu kalsium dalam plasma sebagian besar akan terikat dengan protein (40\%) dan ini berfungsi sebagai sumber cadangan kalsium protein. Dengan kata lain protein sangat penting dalam proses metabolisme kalsium terutama pada proses kalsifikasi tulang dan gigi. Kalsifikasi tulang dan gigi akan menentukan kualitas dan kematangan tulang dan gigi. ${ }^{10}$

Kalsium pada ikan teri baik untuk tulang dan gigi serta mempunyai calming effect. Kalsium ikan teri dapat melancarkan hubungan antar sel yang menurun pada saat seseorang menderita stress dan depresi serta mengendalikan tekanan darah. ${ }^{11}$ Keadaan stress dapat memicu kerusakan tulang dan kegoyangan gigi. Selain itu, ion kalsium akan mengurangi permeabilitas kapiler baru yang terbentuk dalam jaringan yang mengalami reparasi. Ion kalsium penting untuk pembentukan dan pemeliharaan dentin yaitu dengan cara transport aktif ion kalsium pada odontoblas. Odontoblas merupakan sel yang sangat berperan dalam pembentukan dentin dan predentin. Odontoblas mensekresi matriks dentinal dan mundur ke pusat pulpa. ${ }^{12}$

Selain itu, kandungan vitamin A pada ikan teri juga penting untuk pertumbuhan tulang dan gigi. Defisiensi vitamin Aselama proses kehamilan akan menyebabkan penurunan perkembangan jaringan epitel, disfungsi morfogenesis gigi dan diferensiasi odontoblast. Defisiensi vitamin A dapat menyebabkan perubahan kimia pasa dentin yaitu mengurangi proses mineralisasi. ${ }^{13}$

\section{KESIMPULAN}

Ikan teri dapat dimanfaatkan sebagai asupan penting untuk mengoptimalkan pertumbuhan tulang dan gigi. Akan tetapi, dalam mengkonsumsi ikan teri ini ada beberapa hal yang perlu diperhatikan yaitu proses penyimpanan dan pengolahan. Proses penyimpanan dan pengolahan yang salah akan menurunkan zat gizi pada ikan teri dan dapat memicu reaksi alergi.

\section{DAFTAR PUSTAKA}

1. Bozzini E C, Graciela C, Rosa M A, Clarissa B. Bone mineral density and bone strength from mandible of chronically protein restricted rat. 
Acto odontol latinoam2011, 24 (3): 223-28

2. Wirakusumah S E. Mencegah Osteoporosis. 2008. Jakarta: Penebar Plus

3. Saanin H. Taksonomi dan kunci Identifikasi Ikan. 1984. Jakarta: Bina Cipta.

4. Hutomo M, Burhanuddin, A. Djamali, S. Martosewojo. Sumberdaya Ikan Teri di Indonesia. 1987. Jakarta : Proyek Studi Sumberdaya Laut. Pusat Penelitian dan Pengembangan Oseanologi-LIPI.

5. Gunawan H A. Retensi dan Intrusi Fluor pada permukaan email setelah aplikasi dengan Substrat Ikan Teri (Stelephorus sp.). JKG UI 2003, edisi khusus: $793-797$

6. Mescher A. L. Junquieira's Basic Histology Text \& Atlas. 12th Ed. 2010. USA: Mc Graw Hill: 121-139.

7. Yamauchi Nozomi, Hideaki Nagaoka, Shizuko Yamauchi, Fabricio B. Teixeira, Patricia Miguez, Mitsuo Yamauchi. Immunohistological Characterization of Newly Formed Tissues after Regenerative Procedure in Immature Dog Teeth. J Endod 2011, 37 (12):1636-1641

8. Chen F, Terada K, Hanada K. A new method of predicting mandibular length increment on the basis of cervical vertebra. Angle Orthod 2004; 74(5)

9. Rahmana Mansur, Wojciech S. Effect of ovariektomy on biochemical markers of bone turnover (ALP, ACP) and calcium content in rat mandible and teeth. Bull vet inst pulawy 2002, 48: $281-7$

10. Pudyani S P. Reversibilitas kalsifikasi tulang akibat kekurangan protein pre dan post natal. Maj. Ked. Gigi. (Dent. J.) 2005, 38 (3): 115-119

11. Waluyo S, Budhi Marhaendra Putra. 100 Questions and Answers: Menopause atau Mati Haid. 2010. Jakarta: PT Elex Media Komputindo

12. Linde A, Ted Lundgren. From serum to the mineral phase. The role of the odontoblast in calcium transport and mineral formation. Int..l. Un.lliol. 1995, 39: 213-222

13. Decker T R, David A S, Connie C M. Nutrition and Oral Medicine. 2005. New Jersey: Humana Press 